\title{
Current Uses of Poly(lactic-co-glycolic acid) in the Dental Field: A Comprehensive Review
}

\author{
Maria Justina Roxana Virlan, ${ }^{1}$ Daniela Miricescu, ${ }^{1}$ Alexandra Totan, ${ }^{1}$ Maria Greabu, \\ Cristiana Tanase, ${ }^{2,3}$ Cristina M. Sabliov, ${ }^{4}$ Constantin Caruntu, ${ }^{5}$ and Bogdan Calenic ${ }^{1,2}$ \\ ${ }^{1}$ Department of Biochemistry, Faculty of Dentistry, University of Medicine and Pharmacy Carol Davila, 050474 Bucharest, Romania \\ ${ }^{2}$ Biochemistry-Proteomics Department, "Victor Babes" National Institute of Pathology, No. 99 101, Splaiul Independentei, \\ Sector 5, 050096 Bucharest, Romania \\ ${ }^{3}$ Faculty of Medicine, Titu Maiorescu University, Strada Dâmbovnicului 22, 040441 Bucharest, Romania \\ ${ }^{4}$ Agricultural and Biological Engineering Department, Louisiana State University and LSU Ag Center, 149 EB Doran Building, \\ Baton Rouge, LA 70803, USA \\ ${ }^{5}$ Department of Physiology, "Carol Davila" University of Medicine and Pharmacy, 050474 Bucharest, Romania
}

Correspondence should be addressed to Bogdan Calenic; bcalenic@yahoo.co.uk

Received 8 December 2014; Revised 9 February 2015; Accepted 11 February 2015

Academic Editor: Dennis Douroumis

Copyright (C) 2015 Maria Justina Roxana Virlan et al. This is an open access article distributed under the Creative Commons Attribution License, which permits unrestricted use, distribution, and reproduction in any medium, provided the original work is properly cited.

\begin{abstract}
Poly(lactic-co-glycolic acid) or PLGA is a biodegradable polymer used in a wide range of medical applications. Specifically PLGA materials are also developed for the dental field in the form of scaffolds, films, membranes, microparticles, or nanoparticles. PLGA membranes have been studied with promising results, either alone or combined with other materials in bone healing procedures. PLGA scaffolds have been used to regenerate damaged tissues together with stem cell-based therapy. There is solid evidence that the development of PLGA microparticles and nanoparticles may be beneficial to a wide range of dental fields such as endodontic therapy, dental caries, dental surgery, dental implants, or periodontology. The aim of the current paper was to review the recent advances in PLGA materials and their potential uses in the dental field.
\end{abstract}

\section{Introduction}

Poly(lactic-co-glycolic acid) or PLGA is one of the most successfully used synthetic biodegradable polymers in the medical field being approved by the US Food and Drugs Administration and European Medicine Agency [1]. Biocompatibility, biodegradability, flexibility, and minimal side effects are the main advantages when using this polymer for biomedical applications. Main synthesis [2] and degradation mechanisms are described in Figure 1. The present work describes in detail current PLGA uses in the dental field and the relation between different dental fields such as endodontics, periodontology, dental caries, dental surgery, or dental implants and various PLGA materials: membranes, scaffolds, films, and nano- or microparticles.

\section{PLGA in Dentistry}

PLGA materials prove to be effective in a wide variety of dental applications, as it is shown in Figure 2. They are used in a multitude of ways, from developing screws for bone fixation [3-5], treating periodontal pathogens [6], and producing buccal mucosa [7] or in direct pulp-capping procedures $[8,9]$. PLGA can be used in periodontal treatment, for better local administration of antibiotics and to decrease the systemic side effects of general antibiotic delivery [10], in the form of PLGA implants [6], disks [10], and dental films [11]. Also, gel composite fabrics of PLGA can be used in bone regeneration [12], as high degradable PLGA and $\mathrm{SiO}(2)-\mathrm{CaO}$ gel nonwoven fabrics that were exposed to simulated body fluid for 1 week led to a deposition of a layer of apatite crystals on 


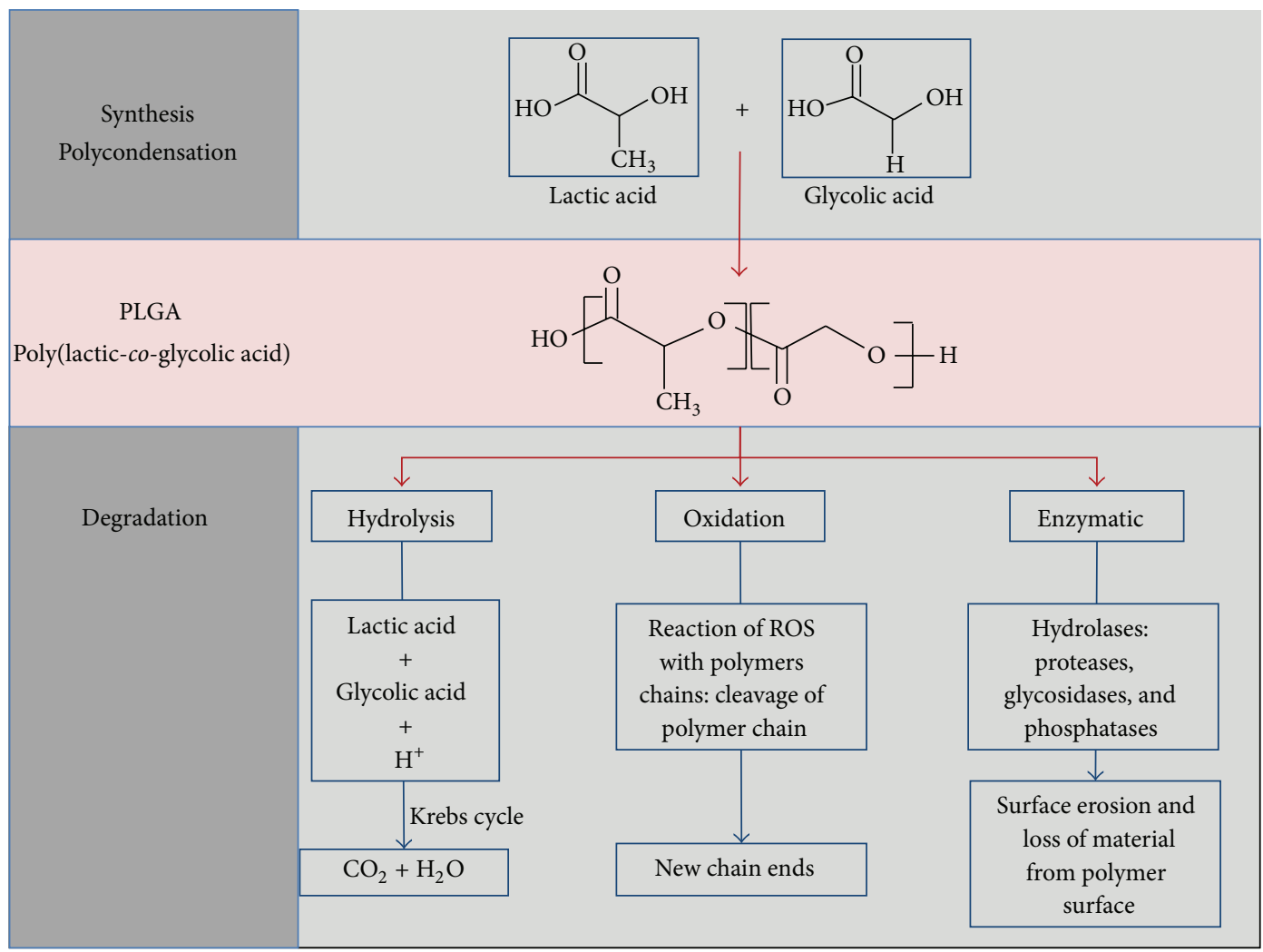

Figure 1: PLGA, poly(lactic-co-glycolic acid), synthesis and degradation. The main reaction used to obtain PLGA is ring opening polymerization and polycondensation of lactic and glycolic acids. Most important mechanisms of PLGA degradation involve hydrolysis, oxidation, and enzymatic degradation.

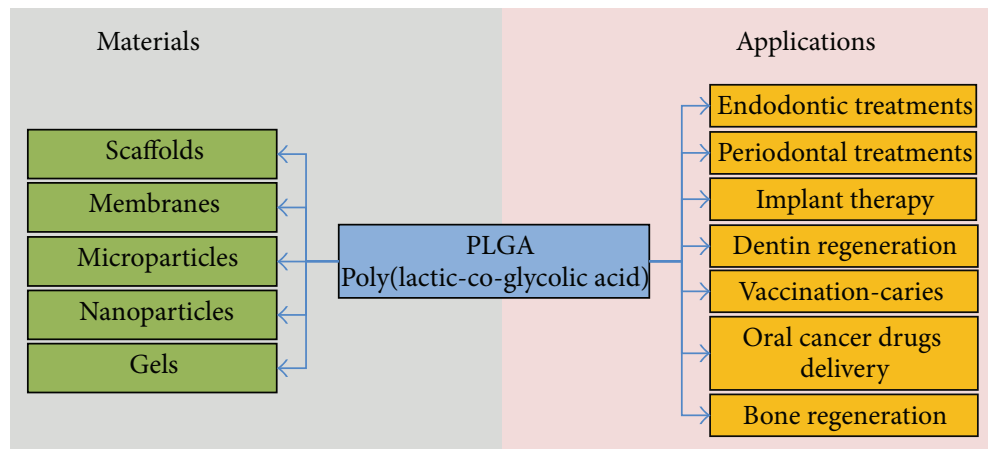

Figure 2: Most common PLGA materials and their applications in the dental field.

their surface [12]. Granular composite of gatifloxacin-loaded PLGA and b-tricalcium phosphate is local delivery means in the treatment of osteomyelitis, as the composite managed to slowly deliver gatifloxacin and showed sufficient bacterial activity in vitro against Streptococcus milleri and Bacteroides fragilis, microorganisms responsible for osteomyelitis. Also, after only 4-week implantation GFLX-loaded PLGA and $\beta$ TCP managed to significantly reduce the inflammation and support the osteoconduction and vascularization of the treated sites in rabbit mandible [13]. Moreover, sterilized
PLGA scaffold is a promising material for producing tissueengineered buccal mucosa [7]. Additionally, PLGA composites with bioceramics can be used in direct pulp capping $[9,14]$ either by incorporating growth factors into PLGA microparticles [14] or by direct pulp capping with PLGA composites of mechanically exposed teeth [9]. However no hard tissue was observed in direct pulp capping with PLGA and pulp necrosis was evident due to the low adhesion of PLGA to the pulp despite the biocompatibility shown in cellular test [8]. So, PLGA composites with bioceramics 
TABLE 1: PLGA membranes in animal and human studies.

\begin{tabular}{|c|c|c|c|}
\hline Type of PLGA membranes & Clinical application & Species & Study \\
\hline PGA/PLA membrane + deproteinized bovine bone & $\begin{array}{l}\text { Guided bone regeneration } \\
\text { of bony defects }\end{array}$ & Humans & {$[25]$} \\
\hline PGA/PLA membranes & $\begin{array}{l}\text { Periodontology } \\
\text { (class II furcation) }\end{array}$ & Humans & {$[26]$} \\
\hline PGA/PLA membranes + hydroxyapatite & $\begin{array}{l}\text { Periodontology } \\
\text { (class II furcation) }\end{array}$ & Humans & [26] \\
\hline PLGA membranes & $\begin{array}{l}\text { Bony defects distal to } \\
\text { mandibular second molars }\end{array}$ & Humans & {$[17]$} \\
\hline PLGA membranes & $\begin{array}{l}\text { Guided bone regeneration } \\
\text { around dental implants }\end{array}$ & Humans & {$[27]$} \\
\hline PLGA membranes & Bone regeneration & Dogs & {$[16]$} \\
\hline $\begin{array}{l}\text { PLGA membrane }+ \text { atelocollagen gel }+ \text { rhBMP- } 2 \\
\text { (recombinant human bone morphogenetic protein-2) }\end{array}$ & Mandibular transsections & Rabbits & {$[20]$} \\
\hline $\begin{array}{l}\text { PLGA membrane }+ \text { atelocollagen gel }+ \text { rhBMP- } 2 \\
\text { (recombinant human bone morphogenetic protein }-2)\end{array}$ & Mandibular defects & Rabbits & {$[21]$} \\
\hline PLGA-grafted hyaluronic acid bilayer films & Guided bone regeneration & Rats & {$[22]$} \\
\hline $\begin{array}{l}\text { Polylactic acid-co-glycolic acid-co- } \varepsilon \text {-caprolactone } \\
\text { membrane }\end{array}$ & Bone healing & Dogs & [23] \\
\hline PLGA membranes & Bone healing & Rabbits & {$[18]$} \\
\hline PLGA $/ \mathrm{SiO}_{2} \mathrm{PLGA} / \mathrm{TiO}_{2}$ membranes & Bone healing & Rabbits & {$[24]$} \\
\hline
\end{tabular}

remain a better option than PLGA alone in pulp capping, with better tissue response as compared to calcium hydroxide $[8,9]$. The promising results of the PLGA materials suggest the need for further studies mainly in the domain of delivery of substances to the dental tissues or concerning the pulpcapping abilities exhibited by the PLGA composites.

\section{PLGA Membranes}

A variety of polymeric bioresorbable membranes are used in bone regeneration techniques because they permit singlestep procedures, thus reducing patient discomfort and costs and potential surgical complications [15]. Greater bone regeneration is also achieved when a membrane is applied in periodontal therapy [16]. Considering this, PLGA membranes have been studied with promising results $[17,18]$, either alone or, more recently, combined with other materials. Table 1 indicates the variety of animal and human studies concerning PLGA membranes in dentistry.

PLGA membranes were studied for periodontal regeneration. Scaling and root planning procedures followed by placing PLGA membranes resulted in significant clinical attachment and bone gain in defects distal to the mandibular second molars [17, 19], while recently a bioactive and resorbable PLGA membrane has been used in calvarial defects for improving bone healing in rabbits [18]. Adding various active substances to PLGA membranes led to increased results. Thus PLGA membrane which coated an atelocollagen gel including rhBMP-2 was used for reconstruction of mandible transsections [20] and defects [21] and the histological analyses suggest that the PLGA membrane was gradually absorbed and replaced by fibrous connective or bone tissue [21]. Moreover, PLGA-grafted hyaluronic acid bilayer films have been successfully tested for guided bone regeneration in rats [22] leading to $63.1 \%$ covering of the bone defect area, with no negative effects [22]. Hyaluronic acid-PLGA was synthesized in the form of $150 \mathrm{~nm}$ nanoparticles and afterwards incorporated in a HA-PLGA bilayer blend film of 33 micron, which was fully degraded and absorbed completely in 12 weeks [22]. Also combined macroporous bioresorbable membranes for bone healing were manufactured from a combination of polylactic acid-co-glycolic acid-co- $\varepsilon$-caprolactone (PLGC) [23]. In a 6-month study on canine mandible were used different PLGC membranes alone or reinforced with titanium, and all showed more bone than the controls, even if the membranes were used alone or together with autologous bone [23]. Recent studies used PLGA membranes treated with oxygen plasma and with $\mathrm{SiO}_{2}$ nanoparticles that succeeded to promote $59 \%$ bone neoformation much more than PLGA membranes alone, in a recent experiment on rabbits skull [24].

Other studies focused on the in vivo behavior of different membranes such as collagen, polylactide/polyglycolide copolymer, and citric acid copolymer. Results show no statistical differences between these membranes [16]. Also, the PGA/PLA polyglycolic/polylactic acid copolymer membrane led to relatively similar results compared with the application of collagen membranes [25]. Moreover, no statistically significant differences were observed when connective tissue grafts were used instead of the PLGA membranes [26], suggesting that better results were obtained when hydroxyapatite was added to the polymer membrane [26]. A recent study on 40 patients concluded that the PLGA membrane was able to successfully assess bone regeneration, but the control showed better results at maintaining horizontal thickness of regenerated bone and revealed less soft tissue complications 
TABLE 2: Applications of PLGA scaffolds in dentistry.

\begin{tabular}{|c|c|c|c|}
\hline Type of PLGA scaffold & Additional substances & Application & Study \\
\hline PLGA & $\begin{array}{l}\text { BMP-2 } \\
\text { (bone morphogenetic protein-2) }\end{array}$ & $\begin{array}{l}\text { Bone regeneration around dental } \\
\text { implants }\end{array}$ & {$[41]$} \\
\hline PLGA & $\begin{array}{l}\text { PEG1 } \\
\text { (prostaglandin E1) }\end{array}$ & $\begin{array}{l}\text { Alveolar ridge } \\
\text { preservation/augmentation }\end{array}$ & {$[44]$} \\
\hline PLGA & Simvastatin & Bone formation in extraction sockets & {$[42]$} \\
\hline PLGA-gelatin sponge & $\begin{array}{l}\text { rhBMP-2 } \\
\text { (recombinant human bone } \\
\text { morphogenetic protein-2) }\end{array}$ & Alveolar ridge augmentation & {$[46]$} \\
\hline PLGA/calcium phosphate cement & & Bone ingrowth & {$[52]$} \\
\hline PLGA + autogenous bone graft & & Bone regeneration around implants & {$[40]$} \\
\hline PLGA/low crystalline apatite & & Bone regeneration & {$[53]$} \\
\hline PLGA/calcium phosphates & & $\begin{array}{l}\text { Maintaining alveolar bone } \\
\text { height/augmenting alveolar bone height } \\
\text { through standard sinus lift approaches }\end{array}$ & {$[28]$} \\
\hline PLGA + beta-tricalcium phosphate & & Bone and cementum regeneration & {$[55]$} \\
\hline PLGA/CaP (calcium phosphate) & & $\begin{array}{l}\text { Periodontal regeneration of class II } \\
\text { furcation defects }\end{array}$ & {$[50]$} \\
\hline PLGA + bone allograft & $\begin{array}{l}\text { rhBMP-2 } \\
\text { (osteoinductive protein) }\end{array}$ & Alveolar ridge augmentation & {$[43]$} \\
\hline PLGA & $\begin{array}{l}\text { Simvastatin and } \\
\text { SDF- } 1 \alpha \\
\text { (stromal cell derived factor- } 1 \alpha \text { ) }\end{array}$ & Bone regeneration & {$[45]$} \\
\hline PLGA/ $\beta$-tricalcium phosphate & Fibroblast growth factor-2 & Bone augmentation & {$[54]$} \\
\hline
\end{tabular}

[27]. Overall, the process of adding bone promoting factors or other materials to the PLGA membranes seems to improve the results $[20-22,24]$ in bone tissue regeneration.

\section{PLGA Scaffolds}

PLGA scaffolds are currently used as standalone biomaterials, cell carriers, or drug delivery devices [28]. Research in medicine benefits from the development of the PLGA scaffolds founding many potential applications in fields like cardiac tissue regeneration [29], wound healing [30], guided bone regeneration of bone tissue [31,32], delivery of growth factors and genes [33], and culture of stem cells [34, 35]. Over the last years, many efforts in bone tissue engineering have been dedicated to the development of biodegradable scaffolds with both excellent biocompatibility and mechanical properties mimicking those of natural bone tissues [36, 37]. PLGA scaffolds have been used to regenerate damaged tissues, for example, in bone formation [38] or in regenerative dentistry, together with stem cell-based therapy [39]. Table 2 shows studies concerning the applications of PLGA scaffolds in bone healing and regeneration. Bone formation was obtained with PLGA carriers incorporated with autogenous bone graft [40] or different bone promoting substances such as bone morphogenetic protein-2 BMP-2 [41] or simvastatin [42]. Alveolar ridge augmentation, much needed in dental implant therapy, could also profit due to the PLGA materials [43], as atrophic sites were reconstructed using bioresorbable PLGA, bone allograft, and an osteoinductive protein such as rhBMP2 [43]. Sockets were significantly greater in rats treated after extraction with PLGA/PEG1, after only 4 weeks of implantation [44]. Also PLGA scaffolds loaded with simvastatin and SDF- $1 \alpha$ promoted bone regeneration significantly more than controls in mouse calvarial defects [45]. Moreover, the addition of recombinant human bone morphogenetic proteins to the PLGA-gelatin sponge scaffolds showed significantly greater bone formation with no immune or other adverse reactions in alveolar ridge augmentation in dogs [46].

Composite PLGA/CaP scaffolds have also been applied in bone regeneration procedures (alone or in combination with osteoblast cells [28, 47-52]). PLGA/CaP (calcium phosphate) bilayered biomaterial was employed with greater periodontal regeneration in class II furcation defects in dogs than traditional flexible membranes, showing greater bone volumetric values, trabecular number, and trabecular thickness [50]. Besides PLGA/CaP, other composites such as PLGA/apatite scaffolds [53] and PLGA/ $\beta$-tricalcium phosphate scaffolds [54] have showed to be bioeffective in bone formation $[53,54]$. Significantly greater cementum and bone were formed in dogs periodontal defects after receiving treatment with rhGDF-5 coated onto beta-tricalcium phosphate (beta-TCP) particles and immersed in a bioresorbable poly(lactic-co-glycolic acid) (PLGA) composite [55]. Moreover PLGA scaffolds alone or in combination with cells were used in maxillary sinus augmentation [56]. Bone regeneration was obtained by seeding on a PLGA scaffold bone marrow mesenchymal stem cells [57] or dental pulp 
TABle 3: Applications of PLGA scaffolds in regenerative dentistry.

\begin{tabular}{lcc}
\hline Type of PLGA scaffolds & Cells seeded on scaffolds & Application \\
\hline PLGA + calcium phosphate & Bone marrow derived cells & Bone formation \\
PLGA & Osteoblast cells & Maxillary sinus augmentation \\
PLGA & Bone marrow stem cells & Bone regeneration \\
PLGA + calcium phosphate & Bone marrow stem cells & Bone regeneration \\
PLGA + nanohydroxyapatite & Tooth bud cells & Cell proliferation and differentiation \\
PLGA/hydroxyapatite & Dental pulp stem cells & Osteoblastic differentiation \\
PLGA/hydroxyapatite & Dedifferentiated fat cells & Bony defects closure \\
PLGA nanofibers & Dental pulp stem cells & Bone regeneration \\
PLGA & Adipose-derived stromal cells & Regeneration of bone, periodontal \\
PLGA & Dental pulp stem cells & ligament and cementum \\
PLGA & Dental pulp stem cells & Dentine/pulp-like tissue \\
PLGA + tricalcium phosphate & Tooth bud cells & Dentine-like structure \\
PLGA + CCN3 & & Dentin-like and \\
(nephroblastoma overexpressed) & Dental pulp stem cells & pulp-like tissues \\
\hline
\end{tabular}

stem cells [58]. Moreover PLGA/hydroxyapatite scaffolds have proven to promote cell proliferation and differentiation of stem cells $[59,60]$. Also bone was regenerated using a PLGA/hydroxyapatite scaffold seeded with dedifferentiated fat cells [61] or PLGA calcium phosphate scaffold with bone marrow stem cells [47]. The addition of bone marrow stem cells to the PLGA calcium phosphate scaffolds showed 20 times more bone formation than scaffolds alone [47].

Polymer materials have been used as scaffolds to guide the dental stem cells with the goal to create tooth-like structures. PLGA materials have been used in dentin regeneration [62] or to produce dentin-like structures [63]. Researchers were able to seed and grow dental pulp stem cells on PLGA scaffolds, and those scaffolds were transplanted in rabbits and appeared to produce osteodentine-like structures as well as tubular bilayered structures of vertically aligned parallel tubules resembling tubular-like dentine [64]. Furthermore, PLGA/tricalcium phosphate with tooth bud cells gave rise to dentin-like and pulp-like tissues [65]. Swine dental pulp stem cells were seeded on PLGA scaffolds and were implanted in rat canals of extracted teeth, which were placed into fresh postextraction sockets of mini pigs [65]. After 10 weeks of implantation the histological analysis showed newly formed organic matrix consistently deposited on the canal walls and the presence of a continuous layer of polarized or nonpolarized cells showing columnar or spindles shaped morphology [65]. Also, stromal cells from the adipose tissue on a PLGA scaffold regenerated bone, periodontal ligament, and cementum layers [66]. Table 3 indicates the main applications of PLGA scaffolds in regenerative dentistry.

Although they show promising results in a variety of applications, the biocompatibility of the PLGA scaffolds is under debate. The degradation products of PLGA (lactic and glycolic acid) can decrease the $\mathrm{pH}$ in the surrounding tissues, causing inflammation or foreign body reactions in vivo [67]. Also, the acidic degradation products have the potential to inhibit apatite crystals formation [68], leading to presumably deficient osteointegration. The hydrophobic proprieties of the bioresorbable polyesters negatively influence their cell adhesion [69]. Moreover, in an attempt to reduce the inflammation and improve the biocompatibility of PLGA different particles have been incorporated with promising results into the PLGA materials: titanium nanoparticles [70], tripolyphosphate nanoparticles [71], demineralized bone particles [67], and nanoapatite particles [72]. Also the PLGA scaffolds were functionalized with fibronectin [69] and the PLGA fibers were coated with apatite layer [73]. Another problem is the fact that salivary born aerobic and anaerobic microorganism adhered significantly more to PLGA compared to other polymeric (PLLA and PLLA-TCP) scaffolds. E. faecalis (a bacteria present in recurrent endodontic infections) and $P$. gingivalis (a periodontitis related pathogen) showed the highest adhesion to the PLGA scaffold, rising concerns about possible implant-associated infections [74].

\section{PLGA Microparticles}

The concept of using polymer-based sustained-release delivery systems to maintain therapeutic drug concentrations for longer periods of time is accepted for decades [75]. Microparticles and nanoparticles are preferred over other methods as a result of their flexibility in preparation and use [76]. Several medical applications of PLGA microparticles include gene delivery [77], anticancer therapy [78], and vaccines [79]. PLGA microparticles have been successfully studied in a wide range of dental fields, such as endodontic therapy [80], dental caries vaccination [81], regenerative dentistry [14], dental surgery [82, 83], or periodontology [84]. Also Table 4 summarizes the main applications of the PLGA microparticles in dentistry. 
TABle 4: Applications of PLGA microparticles in dentistry.

\begin{tabular}{|c|c|c|c|}
\hline Field & PLGA microparticles & Loaded with & Study \\
\hline Endodontic therapy & $\begin{array}{l}\text { PLGA microparticles } \\
\text { with added zein }\end{array}$ & Amoxicillin & {$[80]$} \\
\hline Dental caries vaccination & $\begin{array}{l}\text { PLGA microparticles } \\
\text { coated with chitosan }\end{array}$ & $\begin{array}{l}\text { Recombinant Streptococcusmutans } \\
\text { glucan-binding protein D }\end{array}$ & {$[81]$} \\
\hline $\begin{array}{l}\text { Dental regeneration } \\
\text { (tertiary dentin) }\end{array}$ & $\begin{array}{l}\text { PLGA microparticles } \\
\text { in a PLGA/calcium phosphate cement }\end{array}$ & Growth factors & {$[14]$} \\
\hline Haemostatic device & PLGA microparticles & Thrombin & {$[85]$} \\
\hline \multirow{4}{*}{ periodontal treatment } & PLGAmicroparticles & $\begin{array}{l}\text { Hydroxyapatite } \\
\text { ofloxacine }\end{array}$ & {$[88]$} \\
\hline & PLGA microparticles & Chlorhexidine & {$[87]$} \\
\hline & PDLLA-PLGA microparticles & Growth and differentiation factors & {$[89]$} \\
\hline & PLGA and poly(epsilon-caprolactone) & Doxycycline & {$[84]$} \\
\hline \multirow{2}{*}{ Bone regeneration } & PLGA microparticles & Simvastatin & {$[91]$} \\
\hline & PLGA microparticles & Alendronate sodium & {$[97]$} \\
\hline \multirow{7}{*}{ Implant therapy } & PLGA microparticles & Dexamethasone & {$[94]$} \\
\hline & $\begin{array}{l}\text { PLGA microparticles in collagen } \\
\text { membrane }\end{array}$ & Dexamethasone & {$[93]$} \\
\hline & $\begin{array}{l}\text { PLGA microparticles in } \\
\text { PLGA membrane }\end{array}$ & $\begin{array}{l}\text { VEGF (vascular endothelial growth } \\
\text { factor) }\end{array}$ & {$[92]$} \\
\hline & PLGA microparticles & Insulin & {$[82,83]$} \\
\hline & PLGA microparticles & Basic fibroblast factor & {$[96]$} \\
\hline & PLGA microparticles & Fluvastatin & {$[98]$} \\
\hline & PLGA microparticles & $\begin{array}{l}\text { rhBMp-2 (recombinant human bone } \\
\text { morphogenetic protein-2) }\end{array}$ & {$[99]$} \\
\hline
\end{tabular}

In endodontics PLGA and zein microspheres were able to deliver amoxicillin at significant levels in the root canal [80] and overcame the concentrations levels needed for an appropriate endodontic disinfection [80]. Amoxicillin was elected because it is effective against Enterococcus faecalis, a microorganism responsible for endodontic failure and most resistant to root canal preparation and intracanal dressings [80]. Moreover, PLGA microspheres incorporated with recombinant Streptococcus mutans glucan-binding protein $\mathrm{D}(\mathrm{rGbpD})$ may give rise to a future dental vaccine [81] as a study on immunized rats treated with chitosan-coated PLGA microspheres shows. Growth factors incorporated in PLGA microspheres induce the formation of tertiary dentin [14], while thrombinloaded poly(D,L-lactide-co-glycolide) microspheres formed a new biodegradable haemostatic device [85]. Periodontology can also profit from the controlled delivery proprieties of PLGA microparticles. A wide variety of substances have been incorporated into the PLGA carriers and slowly released locally for periodontal treatment and regeneration: tetracycline [86], doxycycline [84], or chlorhexidine [87]. PLGA microspheres incorporated with hydroxyapatite and ofloxacin were fabricated to be used as a local drug delivery system for periodontitis treatment and showed good results against S. aureus and E. coli [88], while PDLLA-PLGA microparticles filled with growth and differentiation factors were able to accelerate osteogenesis, bone maturation, fibers realignment, and cementogenesis of the periodontal apparatus, in rats maxillae [89]. Bone regeneration is the dental field where most of the studies concerning PLGA microparticles concentrate on. Intracellular delivery of estrogen (a sex steroid that increases bone formation) using cationic PLGA microparticles significantly upregulates osteogenic differentiation of human bone marrow mesenchymal stromal cells by improving the osteogenic differentiation markers ALP and Cbfa-1 expressions after 1 and 2 weeks [90]. PLGA microspheres containing simvastatin [91], growth factors [92], or dexamethasone $[93,94]$ significantly enhanced bone formation. Also PLGA microparticles loaded with growth factors [95, 96] were used for better osteointegration of titanium implants, while biphosphonate PLGA microspheres can be used in the future to treat alveolar bone resorption [97]. Injectable PLGA microspheres containing fluvastatin were developed to enhance osteogenesis around titanium implants in the rat tibia and after a single injection the PLGA microspheres with fluvastatin safely stimulated bone formation around titanium implants and increased the mechanical properties of bone [98]. The biomechanical retention of implants was improved after adding PLGA microparticles loaded with insulin, as an animal study on type I diabetic rats concluded [82]. Moreover, PLGA microparticles were used for better osseointegration of titanium implants, also in type II diabetic rats [95], as insulin-like growth factor I was slowly 
TABLE 5: Applications of PLGA nanoparticles in dental medicine.

\begin{tabular}{|c|c|c|c|}
\hline $\begin{array}{l}\text { Type of PLGA } \\
\text { nanoparticles }\end{array}$ & Loaded with & Dental field & Study \\
\hline PLGA nanoparticles & Minocycline & Periodontal infections & {$[101]$} \\
\hline $\begin{array}{l}\text { Dental implants coated } \\
\text { with } \\
\text { PLGA nanoparticles }\end{array}$ & Basic fibroblast growth factor & Implantology & {$[112]$} \\
\hline PLGA nanoparticles & Methylene-blue photosensitizer & Endodontic infections & {$[108]$} \\
\hline PLGA nanoparticles & Methylene-blue photosensitizer & $\begin{array}{l}\text { Periodontology } \\
\text { (reduction of dental plaque biofilms) }\end{array}$ & {$[109]$} \\
\hline $\begin{array}{l}\text { PLGA nanoparticles } \\
\text { heparin-conjugated }\end{array}$ & $\begin{array}{l}\text { BMP-2 (bone morphogenetic } \\
\text { protein-2) }\end{array}$ & $\begin{array}{l}\text { Bone regeneration } \\
\text { (osteogenic differentiation of bone marrow stem cells) }\end{array}$ & {$[110]$} \\
\hline PLGA nanoparticles & Simvastatin & $\begin{array}{l}\text { Bone regeneration } \\
\text { (enhanced osteogenesis of bone marrow mesenchymal } \\
\text { stem cells) }\end{array}$ & {$[111]$} \\
\hline
\end{tabular}

released for 30-40 days by PLGA microparticles and led to bone deposition around the interface of titanium implants [95]. A scaffold incorporated with PLGA microparticles loaded with a bone morphogenetic protein (rhBMP-2) was more effective to induce implant osseointegration than the same scaffold with the protein directly encapsulated without the PLGA microparticles [99]. Microparticles usage also raised several practical problems. Thus when the particles were studied in implant therapy procedures, some authors reported loss of PLGA drugs during implant placement. Different approaches, such as inserting blood mixed with PLGA microspheres into the implant hole $[82,95]$ or adding the blood mixed with PLGA on the titanium implants [96], showed significant loss of PLGA microparticles, because of the mechanical friction.

The multitude of dental applications in which PLGA particles can be used is encouraging. The promising results in the bone regeneration field and periodontology may need further studies and clinical trials. Overall, microparticles of polylactic-polyglycolic acids seem to be a promising controlled delivery device in dental treatment.

\section{PLGA Nanoparticles}

Microparticles and nanoparticles are mainly designed as targeted drug delivery systems with the aim of minimizing the side effects associated with the use of the free drugs. Various terms have been used to describe the nanoparticles: nanocarriers, nanovehicles, nanosystem, nanodisc, nanoworm, nanorod, nanotube, drug-polymer conjugates, drugprotein conjugates, liposomes, polymer micelles, dendrimers, and drug nanocrystals [100]. Nanoparticles provide a wide range of advantages such as smaller particle size which facilitates the penetration into the cells, higher entrapment efficiency for increased drug release, lower minimum inhibitory concentration, and minimum bacterial concentrations meaning that a better antibacterial activity is achieved with a smaller amount of drug [101]. In the medical field PLGA nanoparticles were developed as gene carriers [102] and also they have been extensively studied as vaccine delivery systems [103-105] or in the anticancer therapy [106, 107]. Targeted PLGA nanoparticles but not microparticles specifically deliver antigen to human dendritic cells [104].

Nanoparticles of PLGA can be used in a wide variety of applications in dental medicine, as shown in Table 5. Minocycline-loaded PLGA nanoparticles showed better antibacterial activity than the use of free minocycline [101] and can provide a potential carrier system for the transport of antibiotics to periodontal tissues. The inhibition zone of minocycline-loaded nanoparticles $(9.2 \mathrm{~mm})$ was greater than that of free minocycline $(3.5 \mathrm{~mm})$ against Aggregatibacter actinomycetemcomitans, the most important pathogen in periodontal infections [101]. Moreover, methylene-blue loaded PLGA nanoparticles showed a greater photodynamic effect than would free $\mathrm{MB}$ and exhibited approximately one order of magnitude killing of E. faecalis biofilm species (a microorganism found in endodontic failures) in experimentally infected root canals of human extracted teeth [108]. Also methylene-blue loaded PLGA nanoparticles exhibited a greater photodynamic effect than free $\mathrm{MB}$ in suspensions of human dental plaque bacteria as well as in biofilms collected from 14 patients with chronic periodontitis [109]. So, PLGA nanoparticles loaded with methylene-blue photosensitizer could be used in endodontic infections [108] as well as in the reduction of human dental plaque bacteria found in patients with chronic periodontitis [109]. Additionally, PLGA nanoparticles add significant improvements to bone regeneration techniques, delivering growth and differentiation factors with promising results. The delivery of PLGA nanoparticles loaded with bone morphogenetic protein-2 to bone marrow mesenchymal stem cells induced far more extensive bone formation in vivo than either implantation of the nanoparticles loaded with BMP-2 alone or osteogenically differentiated stem cells [110]. Also, PLGA nanoparticles containing simvastatin were used to enhance osteogenesis of bone marrow mesenchymal stem cells, which can be further used in bone regeneration [111]. Nanoparticles of PLGA with growth factor have also been used with success in implant therapy, stimulating the bone formation adjacent to the surface of a dental implant inserted in bone 
[110]. The histomorphometric analysis showed a $44 \%$ mean bone-to-implant contact percentage, after only 12 weeks of implantation in rabbit tibiae [112]. Results obtained in these studies are promising, but further experiments are needed to test the effects of applying nanoparticles of PLGA in dental treatments.

\section{PLGA Limitations}

In conclusion, to date, PLGA membranes have controversial results when used alone in bone regeneration therapy $[16,25-$ 27]. Some authors suggested that PLGA has limited benefic effects in bone [113] and periodontal [114] regeneration. Moreover, oral microorganisms (such as S. mutans, E. faecalis, P. nigrescens, $P$. gingivalis, $S$. sanguis, and C. albicans) seem to have a good adherence to the PLGA scaffolds in vitro and this could result in bacterial-related infections in vivo [115]. Research should be intensified and extended in order to overcome the practical problems encountered in the manipulation of the PLGA microparticles [82]. And we must also consider the insufficient data concerning PLGA nanoparticles in the dental field.

\section{Conclusions}

Due to their biocompatibility, PLGA materials have been successfully studied in almost all dental fields, from endodontics to periodontology and implantology. The promising results of the in vitro and in vivo experiments suggest that further studies concerning PLGA applications should be undertaken in dental research.

\section{Conflict of Interests}

The authors declare that there is no conflict of interests regarding the publication of this paper.

\section{Acknowledgments}

Bogdan Calenic acknowledges that this paper is partly supported by the Sectorial Operational Programme Human Resources Development (SOPHRD), financed by the European Social Fund and the Romanian Government under the Contract no. POSDRU 141531. Daniela Miricescu would like to thank the Young Scientist Grant 2014-2016 received from University of Medicine and Pharmacy Carol Davila, Bucharest, Romania. Maria Justina Roxana Virlan acknowledges that this paper is partially supported by the Sectorial Operational Programme Human Resources Development (SOP HRD), financed by the European Social Fund and by the Romanian Government under the Contract no. SOP HRD/159/1.5/S/135760.

\section{References}

[1] F. Danhier, E. Ansorena, J. M. Silva, R. Coco, A. Le Breton, and V. Préat, "PLGA-based nanoparticles: an overview of biomedical applications," Journal of Controlled Release, vol. 161, no. 2, pp. 505-522, 2012.
[2] E. Marin, M. I. Briceño, and C. Caballero-George, "Critical evaluation of biodegradable polymers used in nanodrugs," International Journal of Nanomedicine, vol. 8, pp. 3071-3091, 2013.

[3] C. Ferretti, "A prospective trial of poly-L-lactic/polyglycolic acid co-polymer plates and screws for internal fixation of mandibular fractures," International Journal of Oral and Maxillofacial Surgery, vol. 37, no. 3, pp. 242-248, 2008.

[4] S. Park, J. H. Kim, I. H. Kim et al., "Evaluation of poly(lacticco-glycolic acid) plate and screw system for bone fixation," The Journal of Craniofacial Surgery, vol. 24, no. 3, pp. 1021-1025, 2013.

[5] P. Stockmann, H. Böhm, O. Driemel, J. Mühling, and H. Pistner, "Resorbable versus titanium osteosynthesis devices in bilateral sagittal split ramus osteotomy of the mandible-the results of a two centre randomised clinical study with an eight-year followup," Journal of Cranio-Maxillo-Facial Surgery, vol. 38, no. 7, pp. 522-528, 2010.

[6] M. P. Do, C. Neut, E. Delcourt, T. Seixas Certo, J. Siepmann, and F. Siepmann, "In situ forming implants for periodontitis treatment with improved adhesive properties," European Journal of Pharmaceutics and Biopharmaceutics, vol. 88, no. 2, pp. 342350, 2014.

[7] M. Selim, A. J. Bullock, K. A. Blackwood, C. R. Chapple, and S. MacNeil, "Developing biodegradable scaffolds for tissue engineering of the urethra," BJU International, vol. 107, no. 2, pp. 296-302, 2011.

[8] A. Gala-García, M. B. H. Carneiro, G. A. B. Silva et al., "In vitro and in vivo evaluation of the biocompatibility of a calcium phosphate/poly(lactic-co-glycolic acid) composite," Journal of Materials Science: Materials in Medicine, vol. 23, no. 7, pp. 17851796, 2012.

[9] A. Gala-Garcia, K. I. R. Teixeira, F. H. Lana Wykrota, R. D. Sinisterra, and M. E. Cortés, "Bioceramic/Poly (glycolic)-poly (lactic acid) composite induces mineralized barrier after direct capping of rat tooth pulp tissue," Brazilian Oral Research, vol. 24, no. 1, pp. 8-14, 2010.

[10] F.-Y. Lee, D. W. Chen, C.-C. Hu, Y.-T. Hsieh, S.-J. Liu, and E.-C. Chan, "In vitro and in vivo investigation of drug-eluting implants for the treatment of periodontal disease," AAPS PharmSciTech, vol. 12, no. 4, pp. 1110-1115, 2011.

[11] A. Ahuja, J. Ali, and S. Rahman, "Biodegradable periodontal intrapocket device containing metronidazole and amoxycillin: formulation and characterisation," Die Pharmazie, vol. 61, no. 6, pp. 25-29, 2006.

[12] I. A. Kim and S.-H. Rhee, "Effects of poly(lactic-co-glycolic acid) (PLGA) degradability on the apatite-forming capacity of electrospun PLGA/SiO $2-\mathrm{CaO}$ nonwoven composite fabrics," Journal of Biomedical Materials Research Part B: Applied Biomaterials, vol. 93, no. 1, pp. 218-226, 2010.

[13] G. Tamazawa, A. Ito, T. Miyai et al., "Gatifloxacine-loaded PLGA and $\beta$-tricalcium phosphate composite for treating osteomyelitis," Dental Materials Journal, vol. 30, no. 3, pp. 264273, 2011.

[14] W. Zhang, X. F. Walboomers, and J. A. Jansen, "The formation of tertiary dentin after pulp capping with a calcium phosphate cement, loaded with PLGA microparticles containing TGF- $\beta 1$," Journal of Biomedical Materials Research A, vol. 85, no. 2, pp. 439-444, 2008.

[15] A. Terriza, J. I. Vilches-Pérez, E. de la Orden et al., "Osteoconductive potential of barrier $\mathrm{NanoSiO}_{2}$ PLGA membranes functionalized by plasma enhanced chemical vapour deposition," BioMed Research International, vol. 2014, Article ID 253590, 10 pages, 2014. 
[16] L. Gineste, M. Gineste, L. Bluche et al., "Histomorphometric comparison of three bioabsorbable GTR barrier membranes in the canine model," The International Journal of Periodontics \& Restorative Dentistry, vol. 25, no. 1, pp. 61-71, 2005.

[17] M. Aimetti, E. Pigella, and F. Romano, "Clinical and radiographic evaluation of the effects of guided tissue regeneration using resorbable membranes after extraction of impacted mandibular third molars," The International Journal of Periodontics and Restorative Dentistry, vol. 27, no. 1, pp. 51-59, 2007.

[18] L. S. Karfeld-Sulzer, C. Ghayor, B. Siegenthaler, B. Gjoksi, T. H. Pohjonen, and F. E. Weber, "Comparative study of NMPpreloaded and dip-loaded membranes for guided bone regeneration of rabbit cranial defects," Journal of Tissue Engineering and Regenerative Medicine, 2014.

[19] M. Aimetti and F. Romano, "Use of resorbable membranes in periodontal defects treatment after extraction of impacted mandibular third molars," Minerva Stomatologica, vol. 56, no. 10, pp. 497-508, 2007.

[20] A. Kimura, T. Watanabe, T. Shimizu et al., "Bone repair of rabbit mandibular transsection using rhBMP-2 and atelocollagen gel," European Journal of Medical Research, vol. 11, no. 8, pp. 355-358, 2006.

[21] N. Okafuji, T. Shimizu, T. Watanabe et al., "Tissue reaction to poly (lactic-co-glycolic acid) copolymer membrane in rhBMP used rabbit experimental mandibular reconstruction," European Journal of Medical Research, vol. 11, no. 9, pp. 394-396, 2006.

[22] J. K. Park, J. Yeom, E. J. Oh et al., "Guided bone regeneration by poly(lactic-co-glycolic acid) grafted hyaluronic acid bi-layer films for periodontal barrier applications," Acta Biomaterialia, vol. 5, no. 9, pp. 3394-3403, 2009.

[23] G. Matsumoto, J. Hoshino, Y. Kinoshita et al., "Evaluation of guided bone regeneration with poly(lactic acid-co-glycolic acid-co- $\varepsilon$-caprolactone) porous membrane in lateral bone defects of the canine mandible," The International Journal of Oral \& Maxillofacial Implants, vol. 27, no. 3, pp. 587-594, 2012.

[24] G. Castillo-Dalí, R. Castillo-Oyagüe, A. Terriza et al., "In vivo comparative model of oxygen plasma and nanocomposite particles on PLGA membranes for guided bone regeneration processes to be applied in pre-prosthetic surgery: a pilot study," Journal of Dentistry, vol. 42, no. 11, pp. 1446-1457, 2014.

[25] A. Stavropoulos, A. Sculean, and T. Karring, "GTR treatment of intrabony defects with PLA/PGA copolymer or collagen bioresorbable membranes in combination with deproteinized bovine bone (Bio-Oss)," Clinical Oral Investigations, vol. 8, no. 4, pp. 226-232, 2004.

[26] M. H. Belal, F. A. Al-Noamany, M. M. El-Tonsy, H. M. ElGuindy, and I. Ishikawa, "Treatment of human class II furcation defects using connective tissue grafts, bioabsorbable membrane, and resorbable hydroxylapatite: a comparative study," Journal of the International Academy of Periodontology, vol. 7, no. 4, pp. 114-128, 2005.

[27] D. Schneider, F. E. Weber, U. Grunder, C. Andreoni, R. Burkhardt, and R. E. Jung, "A randomized controlled clinical multicenter trial comparing the clinical and histological performance of a new, modified polylactide-co-glycolide acid membrane to an expanded polytetrafluorethylene membrane in guided bone regeneration procedures," Clinical Oral Implants Research, vol. 25, no. 2, pp. 150-158, 2014.

[28] J. E. Davies, R. Matta, V. C. Mendes, and P. S. Perri De Carvalho, "Development, characterization and clinical use of a biodegradable composite scaffold for bone engineering in oromaxillo-facial surgery," Organogenesis, vol. 6, no. 3, pp. 161-166, 2010.

[29] M. P. Prabhakaran, D. Kai, L. Ghasemi-Mobarakeh, and S. Ramakrishna, "Electrospun biocomposite nanofibrous patch for cardiac tissue engineering," Biomedical Materials, vol. 6, no. 5, Article ID 055001, 2011.

[30] D. W.-C. Chen, J.-Y. Liao, S.-J. Liu, and E.-C. Chan, "Novel biodegradable sandwich-structured nanofibrous drug-eluting membranes for repair of infected wounds: an in vitro and in vivo study," International Journal of Nanomedicine, vol. 7, pp. 763-771, 2012.

[31] A. Doğan, S. Demirci, Y. Bayir et al., "Boron containing poly-(lactide-co-glycolide) (PLGA) scaffolds for bone tissue engineering," Materials Science and Engineering C: Materials for Biological Applications, vol. 44, pp. 246-253, 2014.

[32] D.-X. Wang, Y. He, L. Bi et al., "Enhancing the bioactivity of Poly(lactic-co-glycolic acid) scaffold with a nano-hydroxyapatite coating for the treatment of segmental bone defect in a rabbit model," International Journal of Nanomedicine, vol. 8, pp. 1855-1865, 2013.

[33] W. Ji, Y. Sun, F. Yang et al., "Bioactive electrospun scaffolds delivering growth factors and genes for tissue engineering applications," Pharmaceutical Research, vol. 28, no. 6, pp. 12591272, 2011.

[34] M. Massumi, M. Abasi, H. Babaloo et al., "The effect of topography on differentiation fates of matrigel-coated mouse embryonic stem cells cultured on PLGA nanofibrous scaffolds," Tissue Engineering Part A, vol. 18, no. 5-6, pp. 609-620, 2012.

[35] P. T. Thevenot, A. M. Nair, J. Shen, P. Lotfi, C.-Y. Ko, and L. Tang, "The effect of incorporation of SDF- $1 \alpha$ into PLGA scaffolds on stem cell recruitment and the inflammatory response," Biomaterials, vol. 31, no. 14, pp. 3997-4008, 2010.

[36] T. A. Holland and A. G. Mikos, "Biodegradable polymeric scaffolds. Improvements in bone tissue engineering through controlled drug delivery," Advances in Biochemical Engineering/Biotechnology, vol. 102, pp. 161-185, 2006.

[37] Y. Kang, A. Scully, D. A. Young et al., "Enhanced mechanical performance and biological evaluation of a PLGA coated $\beta$-TCP composite scaffold for load-bearing applications," European Polymer Journal, vol. 47, no. 8, pp. 1569-1577, 2011.

[38] C. Zong, X. Qian, Z. Tang et al., "Biocompatibility and bonerepairing effects: comparison between porous poly-lactic-Coglycolic acid and nano-hydroxyapatite/poly(lactic acid) scaffolds," Journal of Biomedical Nanotechnology, vol. 10, no. 6, pp. 1091-1104, 2014.

[39] F. J. Rodríguez-Lozano, D. García-Bernal, S. Aznar-Cervantes et al., "Effects of composite films of silk fibroin and graphene oxide on the proliferation, cell viability and mesenchymal phenotype of periodontal ligament stem cells," Journal of Materials Science: Materials in Medicine, vol. 25, no. 12, pp. 2731-2741, 2014.

[40] K. S. Hassan, "Autogenous bone graft combined with polylactic polyglycolic acid polymer for treatment of dehiscence around immediate dental implants," Oral Surgery, Oral Medicine, Oral Pathology, Oral Radiology and Endodontology, vol. 108, no. 5, pp. e19-e25, 2009.

[41] A. A. Jones, D. Buser, R. Schenk, J. Wozney, and D. L. Cochran, "The effects of rhBMP-2 around endosseous implants with and without membranes in the canine model," Journal of Periodontology, vol. 77, no. 7, pp. 1184-1193, 2006.

[42] Z. Wu, C. Liu, G. Zang, and H. Sun, "The effect of simvastatin on remodelling of the alveolar bone following tooth extraction," 
International Journal of Oral and Maxillofacial Surgery, vol. 37, no. 2, pp. 170-176, 2008.

[43] B. P. Levin, "Alveolar ridge augmentation: combining bioresorbable scaffolds with osteoinductive bone grafts in atrophic sites. A follow-up to an evolving technique," The Compendium of Continuing Education in Dentistry, vol. 34, no. 3, pp. 178-187, 2013.

[44] G. Iino, K. Nishimura, K. Omura, and S. Kasugai, "Effects of prostaglandin E1 application on rat incisal sockets," The International Journal of Oral \& Maxillofacial Implants, vol. 23, no. 5, pp. 835-840, 2008.

[45] Y. S. Liu, M. E. Ou, H. Liu et al., "The effect of simvastatin on chemotactic capability of SDF- $1 \alpha$ and the promotion of bone regeneration," Biomaterials, vol. 35, no. 15, pp. 4489-4498, 2014.

[46] N. Kawakatsu, S. Oda, A. Kinoshita et al., "Effect of rhBMP-2 with PLGA/gelatin sponge type (PGS) carrier on alveolar ridge augmentation in dogs," Journal of Oral Rehabilitation, vol. 35, no. 9, pp. 647-655, 2008.

[47] M. M. Beloti, L. G. Sicchieri, P. T. de Oliveira, and A. L. Rosa, "The influence of osteoblast differentiation stage on bone formation in autogenously implanted cell-based poly(lactideco-glycolide) and calcium phosphate constructs," Tissue Engineering, Part A, vol. 18, no. 9-10, pp. 999-1005, 2012.

[48] M. M. Beloti, P. T. de Oliveira, P. S. P. de Carvalho, and A. L. Rosa, "Seeding osteoblastic cells into a macroporous biodegradable CaP/PLGA scaffold by a centrifugal force," Journal of Biomaterials Applications, vol. 23, no. 6, pp. 481-495, 2009.

[49] L. G. Sicchieri, G. E. Crippa, P. T. de Oliveira, M. M. Beloti, and A. L. Rosa, "Pore size regulates cell and tissue interactions with PLGA-CaP scaffolds used for bone engineering," Journal of Tissue Engineering and Regenerative Medicine, vol. 6, no. 2, pp. 155-162, 2012.

[50] E. C. Carlo Reis, A. P. B. Borges, M. V. F. Araújo, V. C. Mendes, L. Guan, and J. E. Davies, "Periodontal regeneration using a bilayered PLGA/calcium phosphate construct," Biomaterials, vol. 32, no. 35, pp. 9244-9253, 2011.

[51] T. Ren, J. Ren, X. Jia, and K. Pan, "The bone formation in vitro and mandibular defect repair using PLGA porous scaffolds," Journal of Biomedical Materials Research-Part A, vol. 74, no. 4, pp. 562-569, 2005.

[52] A. S. Plachokova, J. van den Dolder, and J. A. Jansen, “The boneregenerative properties of Emdogain adsorbed onto poly(D,Llactic-coglycolic acid)/calcium phosphate composites in an ectopic and an orthotopic rat model," Journal of Periodontal Research, vol. 43, no. 1, pp. 55-63, 2008.

[53] T. Hayakawa, C. Mochizuki, H. Hara et al., "In vivo evaluation of composites of PLGA and apatite with two different levels of crystallinity," Journal of Materials Science: Materials in Medicine, vol. 21, no. 1, pp. 251-258, 2010.

[54] T. Yoshida, H. Miyaji, K. Otani et al., "Bone augmentation using a highly porous PLGA/ $\beta$-TCP scaffold containing fibroblast growth factor-2," Journal of Periodontal Research, 2014.

[55] D. H. Kwon, F. C. Bisch, R. W. Herold et al., "Periodontal wound healing/regeneration following the application of rhGDF-5 in a $\beta$-TCP/PLGA carrier in critical-size supra-alveolar periodontal defects in dogs," Journal of Clinical Periodontology, vol. 37, no. 7, pp. 667-674, 2010.

[56] C. Zizelmann, R. Schoen, M. C. Metzger et al., "Bone formation after sinus augmentation with engineered bone," Clinical Oral Implants Research, vol. 18, no. 1, pp. 69-73, 2007.

[57] M. K. Marei, M. M. Saad, A. M. El-Ashwah, R. M. Ei-Backly, and M. A. Al-Khodary, "Experimental formation of periodontal structure around titanium implants utilizing bone marrow mesenchymal stem cells: a pilot study," The Journal of Oral Implantology, vol. 35, no. 3, pp. 106-129, 2009.

[58] G. A. X. Acasigua, L. Bernardi, D. I. Braghirolli, M. S. Filho, P. Pranke, and A. C. M. Fossati, "Nanofiber scaffolds support bone regeneration associated with pulp stem cells," Current Stem Cell Research \& Therapy, vol. 9, no. 4, pp. 330-337, 2014.

[59] I. Karadzic, V. Vucic, V. Jokanovic et al., "Effects of novel hydroxyapatite-based 3D biomaterials on proliferation and osteoblastic differentiation of mesenchymal stem cells," Journal of Biomedical Materials Research-Part A, vol. 103, no. 1, pp. 350-357, 2015.

[60] E. H. C. van Manen, W. Zhang, X. F. Walboomers et al., "The influence of electrospun fibre scaffold orientation and nanohydroxyapatite content on the development of tooth bud stem cells in vitro," Odontology, vol. 102, no. 1, pp. 14-21, 2014.

[61] Y. Shirakata, T. Nakamura, Y. Shinohara et al., "An exploratory study on the efficacy of rat dedifferentiated fat cells (rDFATs) with a poly lactic-co-glycolic acid/hydroxylapatite (PLGA/HA) composite for bone formation in a rat calvarial defect model," Journal of Materials Science: Materials in Medicine, vol. 25, no. 3, pp. 899-908, 2014.

[62] X. Wang, H. He, X. Wu, J. Hu, and Y. Tan, "Promotion of dentin regeneration via CCN3 modulation on Notch and BMP signaling pathways," Biomaterials, vol. 35, no. 9, pp. 2720-2729, 2014.

[63] K. Kodonas, C. Gogos, S. Papadimitriou, K. Kouzi-Koliakou, and D. Tziafas, "Experimental formation of dentin-like structure in the root canal implant model using cryopreserved swine dental pulp progenitor cells," Journal of Endodontics, vol. 38, no. 7, pp. 913-919, 2012.

[64] R. M. El-Backly, A. G. Massoud, A. M. El-Badry, R. A. Sherif, and M. K. Marei, "Regeneration of dentine/pulp-like tissue using a dental pulp stem cell/poly(lactic-co-glycolic) acid scaffold construct in New Zealand white rabbits," Australian Endodontic Journal, vol. 34, no. 2, pp. 52-67, 2008.

[65] L. Zheng, F. Yang, H. Shen et al., "The effect of composition of calcium phosphate composite scaffolds on the formation of tooth tissue from human dental pulp stem cells," Biomaterials, vol. 32, no. 29, pp. 7053-7059, 2011.

[66] D. Akita, M. Morokuma, Y. Saito et al., "Periodontal tissue regeneration by transplantation of rat adipose-derived stromal cells in combination with PLGA-based solid scaffolds," Biomedical Research, vol. 35, no. 2, pp. 91-103, 2014.

[67] S. J. Yoon, S. H. Kim, H. J. Ha et al., "Reduction of inflammatory reaction of poly(D,L-lactic-co-glycolic acid) using demineralized bone particles," Tissue Engineering Part A, vol. 14, no. 4, pp. 539-547, 2008.

[68] S. H. Rhee and J. L. Seung, "Effect of acidic degradation products of poly(lactic-co-glycolic)acid on the apatite-forming ability of poly(lactic-co-glycolic)acid-siloxane nanohybrid material," Journal of Biomedical Materials Research-Part A, vol. 83, no. 3, pp. 799-805, 2007.

[69] D. M. Campos, K. Gritsch, V. Salles, G. N. Attik, and B. Grosgogeat, "Surface entrapment of fibronectin on electrospun PLGA scaffolds for periodontal tissue engineering," BioResearch Open Access, vol. 3, no. 3, pp. 117-126, 2014.

[70] H. Liu, E. B. Slamovich, and T. J. Webster, "Less harmful acidic degradation of poly(lactic-co-glycolic acid) bone tissue engineering scaffolds through titania nanoparticle addition," International Journal of Nanomedicine, vol. 1, no. 4, pp. 541-545, 2006. 
[71] S. Xie, Q. Zhu, B. Wang et al., "Incorporation of tripolyphosphate nanoparticles into fibrous poly(lactide-co-glycolide) scaffolds for tissue engineering," Biomaterials, vol. 31, no. 19, pp. 5100-5109, 2010.

[72] W. Ji, F. Yang, H. Seyednejad et al., "Biocompatibility and degradation characteristics of PLGA-based electrospun nanofibrous scaffolds with nanoapatite incorporation," Biomaterials, vol. 33, no. 28, pp. 6604-6614, 2012.

[73] I. A. Kim and S.-H. Rhee, "Apatite coating of electrospun PLGA fibers using a PVA vehicle system carrying calcium ions," Journal of Biomaterials Science: Polymer Edition, vol. 21, no. 8-9, pp. 1127-1141, 2010.

[74] A. Al-Ahmad, C. Schubert, C. Carvalho et al., "Comparison of bacterial adhesion and cellular proliferation on newly developed three-dimensional scaffolds manufactured by rapid prototyping technology," Journal of Biomedical Materials Research Part A, vol. 98, no. 2, pp. 303-311, 2011.

[75] Y. Wang, X. Yang, W. Liu, F. Zhang, Q. Cai, and X. Deng, "Controlled release behaviour of protein-loaded microparticles prepared via coaxial or emulsion electrospray," Journal of Microencapsulation, vol. 30, no. 5, pp. 490-497, 2013.

[76] Q. Xu, M. Hashimoto, T. T. Dang et al., "Preparation of monodisperse biodegradable polymer microparticles using a microfluidic flow-focusing device for controlled drug delivery," Small, vol. 5, no. 13, pp. 1575-1581, 2009.

[77] J. Intra and A. K. Salem, "Fabrication, characterization and in vitro evaluation of poly(D,L-lactide-co-glycolide) microparticles loaded with polyamidoamine-plasmid DNA dendriplexes for applications in nonviral gene delivery," Journal of Pharmaceutical Sciences, vol. 99, no. 1, pp. 368-384, 2010.

[78] M. Farazuddinm, B. Sharma, A. A. Khan, B. Joshi, and M. Owais, "Anticancer effcacy of perillyl alcohol-bearing PLGA microparticles," International Journal of Nanomedicine, vol. 7, pp. 35-47, 2012.

[79] D. Pawar, A. K. Goyal, S. Mangal et al., "Evaluation of mucoadhesive PLGA microparticles for nasal immunization," The AAPS Journal, vol. 12, no. 2, pp. 130-137, 2010.

[80] F. F. O. Sousa, A. Luzardo-Álvarez, A. Pérez-Estévéz, R. SeoanePrado, and J. Blanco-Méndez, "Development of a novel AMXloaded PLGA/zein microsphere for root canal disinfection," Biomedical Materials, vol. 5, no. 5, Article ID 55008, 2010.

[81] H. Zhao, B. Wu, H. Wu et al., "Protective immunity in rats by intranasal immunization with Streptococcus mutans glucanbinding protein $\mathrm{D}$ encapsulated into chitosan-coated poly (lactic-co-glycolic acid) microspheres," Biotechnology Letters, vol. 28, no. 16, pp. 1299-1304, 2006.

[82] Y. Han, Q. Zeng, E. Lingling, D. Wang, H. He, and H. Liu, "Sustained Topical delivery of insulin from fibrin gel loaded with poly(lactic-co-glycolic acid) microspheres improves the biomechanical retention of titanium implants in type 1 diabetic rats," Journal of Oral and Maxillofacial Surgery, vol. 70, no. 10, pp. 2299-2308, 2012.

[83] Y. Han, X. Zhang, E. LingLing, D. Wang, and H. Liu, "Sustained local delivery of insulin for potential improvement of periimplant bone formation in diabetes," Science China Life Sciences, vol. 55, no. 11, pp. 948-957, 2012.

[84] R. C. Mundargi, S. Srirangarajan, S. A. Agnihotri et al., "Development and evaluation of novel biodegradable microspheres based on poly(d,l-lactide-co-glycolide) and poly(epsiloncaprolactone) for controlled delivery of doxycycline in the treatment of human periodontal pocket: in vitro and in vivo studies," Journal of Controlled Release, vol. 119, no. 1, pp. 59-68, 2007.

[85] R. Smeets, F. Gerhards, J. M. Stein et al., "A novel hemostatic delivery device for thrombin: biodegradable poly(D,L-lactideco-glycolide) 50:50 microspheres," Journal of Biomedical Materials Research Part A, vol. 96, no. 1, pp. 177-185, 2011.

[86] D. Z. Liu, W. P. Chen, C. P. Lee, S. L. Wu, Y. C. Wang, and T. W. Chung, "Effects of alginate coated on PLGA microspheres for delivery tetracycline hydrochloride to periodontal pockets," Journal of Microencapsulation, vol. 21, no. 6, pp. 643-652, 2004.

[87] I. C. Yue, J. Poff, M. E. Cortés et al., "A novel polymeric chlorhexidine delivery device for the treatment of periodontal disease," Biomaterials, vol. 25, no. 17, pp. 3743-3750, 2004.

[88] T. Jamal, M. A. Rahman, M. A. Mirza, A. K. Panda, S. Talegaonkar, and Z. Iqbal, "Formulation, antimicrobial and toxicity evaluation of Bioceramic based ofloxacin loaded biodegradable microspheres for periodontal infection," Current Drug Delivery, vol. 9, no. 5, pp. 515-526, 2012.

[89] P.-C. Chang, A. S. Dovban, L. P. Lim, L. Y. Chong, M. Y. Kuo, and C.-H. Wang, "Dual delivery of PDGF and simvastatin to accelerate periodontal regeneration invivo," Biomaterials, vol. 34, no. 38, pp. 9990-9997, 2013.

[90] L. Hong, Y. Krishnamachari, D. Seabold, V. Joshi, G. Schneider, and A. K. Salem, "Intracellular release of $17-\beta$ estradiol from cationic polyamidoamine dendrimer surface-modified poly (lactic-co-glycolic acid) microparticles improves osteogenic differentiation of human mesenchymal stromal cells," Tissue Engineering Part C: Methods, vol. 17, no. 3, pp. 319-325, 2011.

[91] Y. Naito, T. Terukina, S. Galli et al., "The effect of simvastatinloaded polymeric microspheres in a critical size bone defect in the rabbit calvaria," International Journal of Pharmaceutics, vol. 461, no. 1-2, pp. 157-162, 2014.

[92] Y. Yonamine, T. Matsuyama, T. Sonomura et al., "Effectable application of vascular endothelial growth factor to critical sized rat calvaria defects," Oral Surgery, Oral Medicine, Oral Pathology, Oral Radiology and Endodontology, vol. 109, no. 2, pp. 225-231, 2010.

[93] Z.-G. Piao, J.-S. Kim, J.-S. Son et al., "Osteogenic evaluation of collagen membrane containing drug-loaded polymeric microparticles in a rat calvarial defect model," Tissue Engineering $A$, vol. 20, no. 23-24, pp. 3322-3331, 2014.

[94] J. S. Son, Y.-A. Choi, E.-K. Park, T.-Y. Kwon, K.-H. Kim, and K.-B. Lee, "Drug delivery from hydroxyapatite-coated titanium surfaces using biodegradable particle carriers," Journal of Biomedical Materials Research-Part B Applied Biomaterials, vol. 101, no. 2, pp. 247-257, 2013.

[95] F. Wang, Y.-L. Song, C.-X. Li et al., "Sustained release of insulin-like growth factor-1 from poly(lactide-co-glycolide) microspheres improves osseointegration of dental implants in type 2 diabetic rats," European Journal of Pharmacology, vol. 640, no. 1-3, pp. 226-232, 2010.

[96] G.-K. Zou, Y.-L. Song, W. Zhou et al., "Effects of local delivery of bFGF from PLGA microspheres on osseointegration around implants in diabetic rats," Oral Surgery, Oral Medicine, Oral Pathology and Oral Radiology, vol. 114, no. 3, pp. 284-289, 2012.

[97] S. Samdancioglu, S. Calis, M. Sumnu, and A. A. Hincal, "Formulation and in vitro evaluation of bisphosphonate loaded microspheres for implantation in osteolysis," Drug Development and Industrial Pharmacy, vol. 32, no. 4, pp. 473-481, 2006.

[98] T. Masuzaki, Y. Ayukawa, Y. Moriyama et al., "The effect of a single remote injection of statin-impregnated poly (lactic-coglycolic acid) microspheres on osteogenesis around titanium 
implants in rat tibia," Biomaterials, vol. 31, no. 12, pp. 3327-3334, 2010.

[99] S. Shi, X. Cheng, J. Wang, W. Zhang, L. Peng, and Y. Zhang, "RhBMP-2 microspheres-loaded chitosan/collagen scaffold enhanced osseointegration: an experiment in dog," Journal of Biomaterials Applications, vol. 23, no. 4, pp. 331-346, 2009.

[100] I. K. Kwon, S. C. Lee, B. Han, and K. Park, "Analysis on the current status of targeted drug delivery to tumors," Journal of Controlled Release, vol. 164, no. 2, pp. 108-114, 2012.

[101] T. S. J. Kashi, S. Eskandarion, M. Esfandyari-Manesh et al., "Improved drug loading and antibacterial activity of minocycline-loaded PLGA nanoparticles prepared by solid/oil/ water ion pairing method," International Journal of Nanomedicine, vol. 7, pp. 221-234, 2012.

[102] M. N. V. R. Kumar, S. S. Mohapatra, X. Kong, P. K. Jena, U. Bakowsky, and C.-M. Lehr, "Cationic poly(lactide-co-glycolide) nanoparticles as efficient in vivo gene transfection agents," Journal of Nanoscience and Nanotechnology, vol. 4, no. 8, pp. 990-994, 2004.

[103] L. J. Cruz, R. A. Rosalia, J. W. Kleinovink, F. Rueda, C. W. Löwik, and F. Ossendorp, "Targeting nanoparticles to CD40, DEC-205 or CD11c molecules on dendritic cells for efficient $\mathrm{CD}^{+} \mathrm{T}$ cell response: a comparative study," Journal of Controlled Release, vol. 192, pp. 209-218, 2014.

[104] L. J. Cruz, P. J. Tacken, I. S. Zeelenberg et al., “Tracking targeted bimodal nanovaccines: immune responses and routing in cells, tissue, and whole organism," Molecular Pharmaceutics, vol. 11, no. 12, pp. 4299-4313, 2014.

[105] S. Hamdy, A. Haddadi, A. Shayeganpour, J. Samuel, and A. Lavasanifar, "Activation of antigen-specific $\mathrm{T}$ cell-responses by mannan-decorated PLGA nanoparticles," Pharmaceutical Research, vol. 28, no. 9, pp. 2288-2301, 2011.

[106] E. Nance, C. Zhang, T.-Y. Shih, Q. Xu, B. S. Schuster, and J. Hanes, "Brain-penetrating nanoparticles improve Paclitaxel efficacy in malignant glioma following local administration," ACS Nano, vol. 8, no. 10, pp. 10655-10664, 2014.

[107] M. Noori Koopaei, M. R. Khoshayand, S. H. Mostafavi et al., "Docetaxel loaded PEG-PLGA nanoparticles: optimized drug loading, in-vitro cytotoxicity and in-vivo antitumor effect," Iranian Journal of Pharmaceutical Research, vol. 13, no. 3, pp. 819-833, 2014.

[108] T. C. Pagonis, J. Chen, C. R. Fontana et al., "Nanoparticle-based endodontic antimicrobial photodynamic therapy," Journal of Endodontics, vol. 36, no. 2, pp. 322-328, 2010.

[109] V. Klepac-Ceraj, N. Patel, X. Song et al., "Photodynamic effects of methylene blue-loaded polymeric nanoparticles on dental plaque bacteria," Lasers in Surgery and Medicine, vol. 43, no. 7, pp. 600-606, 2011.

[110] S. E. Kim, O. Jeon, J. B. Lee et al., "Enhancement of ectopic bone formation by bone morphogenetic protein-2 delivery using heparin-conjugated PLGA nanoparticles with transplantation of bone marrow-derived mesenchymal stem cells," Journal of Biomedical Science, vol. 15, no. 6, pp. 771-777, 2008.

[111] C.-Z. Wang, Y.-C. Fu, S.-C. Jian et al., "Synthesis and characterization of cationic polymeric nanoparticles as simvastatin carriers for enhancing the osteogenesis of bone marrow mesenchymal stem cells," Journal of Colloid and Interface Science, vol. 432, pp. 190-199, 2014.

[112] S. Y. Lee, J. Y. Koak, S. J. Heo, S. K. Kim, S. J. Lee, and S. Y. Nam, "Osseointegration of anodized titanium implants coated with poly(lactide-co-glycolide)/basic fibroblast growth factor by electrospray," The International Journal of Oral \& Maxillofacial Implants, vol. 25, no. 2, pp. 315-320, 2010.

[113] L. Molly, H. Vandromme, M. Quirynen, E. Schepers, J. L. Adams, and D. van Steenberghe, "Bone formation following implantation of bone biomaterials into extraction sites," Journal of Periodontology, vol. 79, no. 6, pp. 1108-1115, 2008.

[114] L. Minenna, F. Herrero, M. Sanz, and L. Trombelli, "Adjunctive effect of a polylactide/polyglycolide copolymer in the treatment of deep periodontal intra-osseous defects: a randomized clinical trial," Journal of Clinical Periodontology, vol. 32, no. 5, pp. 456461, 2005.

[115] A. Al-Ahmad, M. Wiedmann-Al-Ahmad, C. Carvalho et al., "Bacterial and Candida albicans adhesion on rapid prototypingproduced 3D-scaffolds manufactured as bone replacement materials," Journal of Biomedical Materials Research-Part A, vol. 87, no. 4, pp. 933-943, 2008.

[116] K. Gomi, M. Kanazashi, D. Lickorish, T. Arai, and J. E. Davies, "Bone marrow genesis after subcutaneous delivery of rat osteogenic cell-seeded biodegradable scaffolds into nude mice," Journal of Biomedical Materials Research Part A, vol. 71, no. 4, pp. 602-607, 2004. 

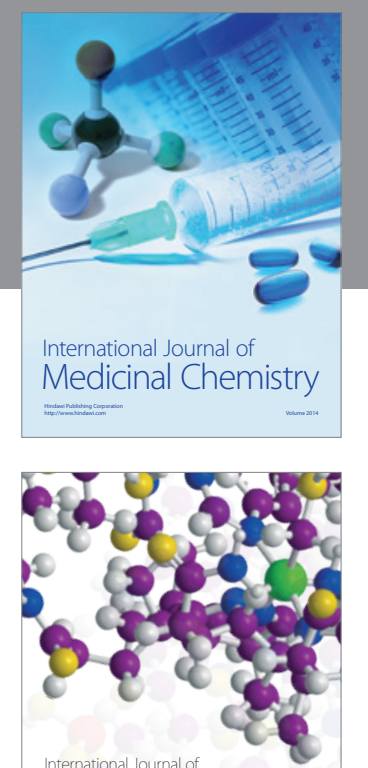

\section{Carbohydrate} Chemistry

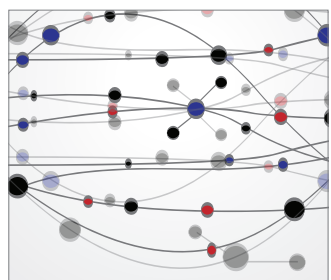

The Scientific World Journal
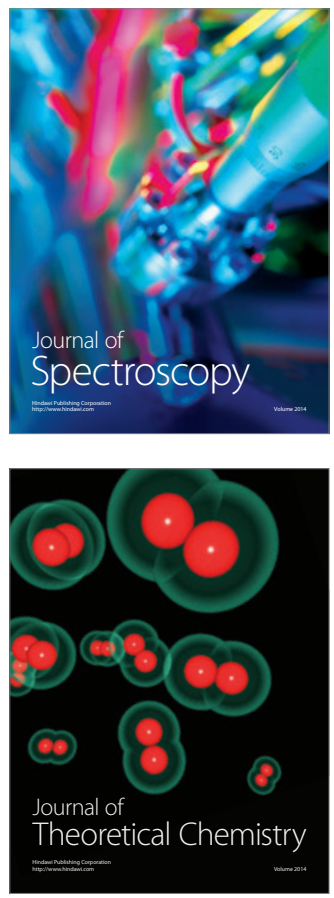
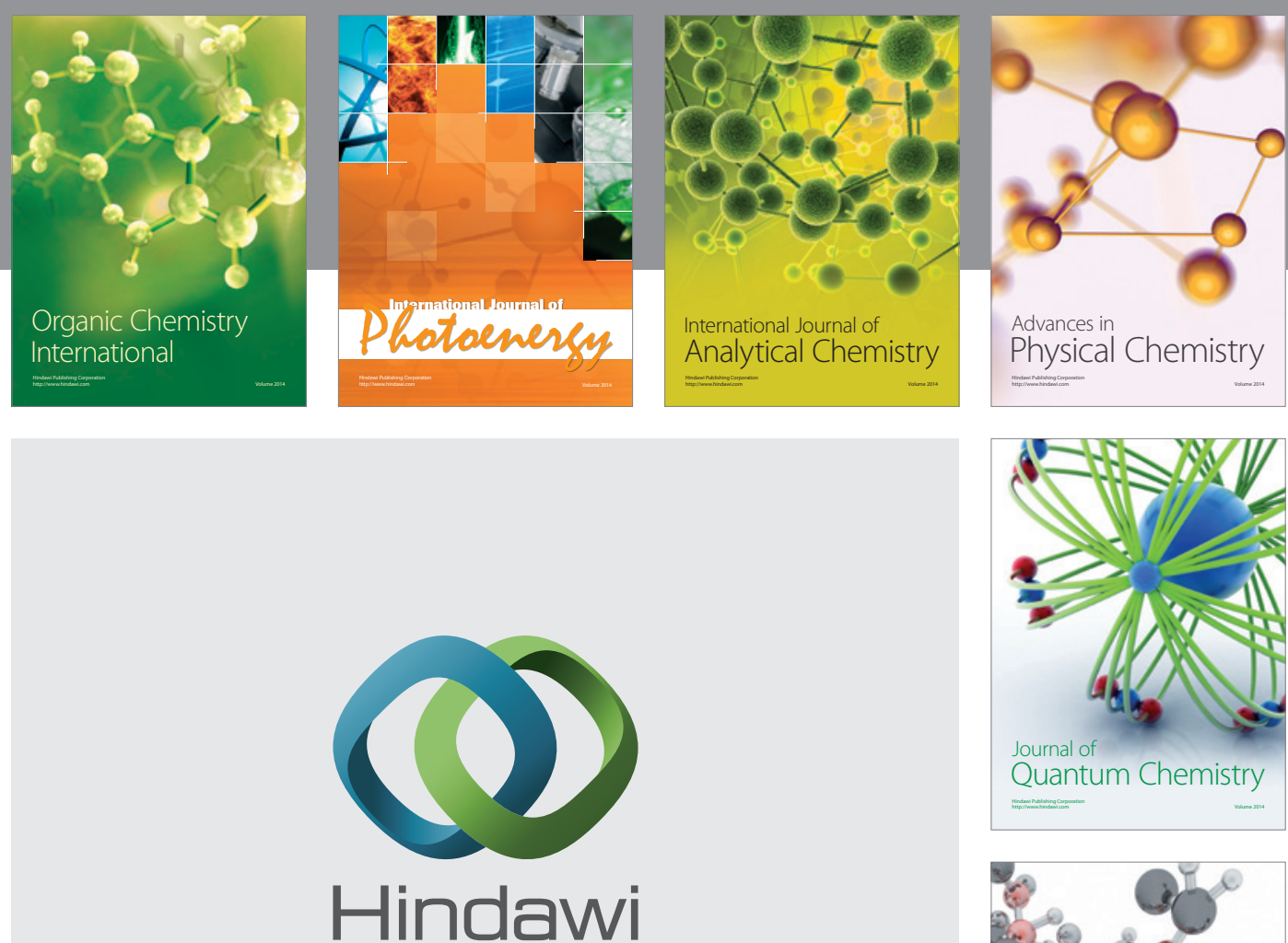

Submit your manuscripts at

http://www.hindawi.com

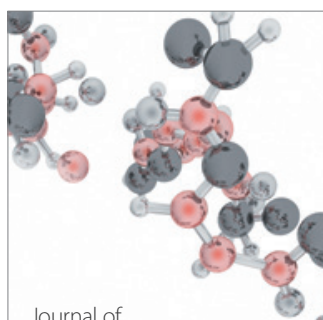

Analytical Methods

in Chemistry

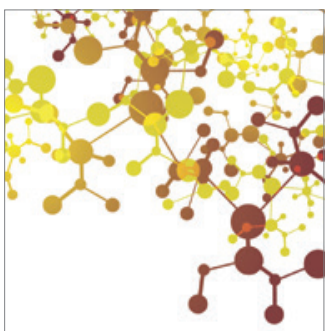

Journal of

Applied Chemistry

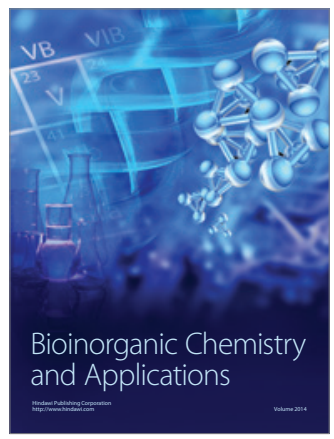

Inorganic Chemistry
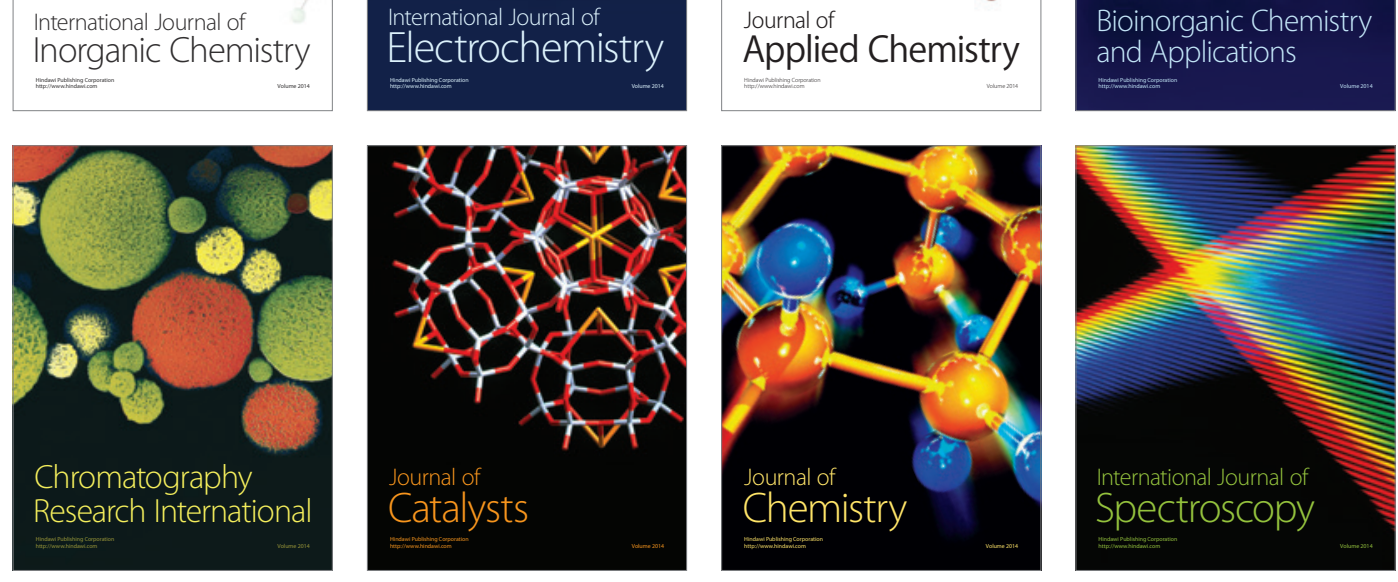